\section{NZ medicine after Cartwright}

"May you live in interesting times," runs the old Chinese curse. Since the Cartwright inquiry reported (20-27 August 1988, p 533) New Zealand doctors have indeed found themselves living in interesting times. The inquiry found that over 20 years treatment had been withheld from some patients with carcinoma of the cervix who attended Auckland's National Women's Hospital. For the latter part of the study the policy adopted was not in line with internationally accepted management, and yet at no stage were the patients informed of the risks of that policy or the treatment options available. Some women developed invasive lesions but were denied adequate treatment because of the theoretical commitments of the principal investigator, Professor H Green. In addition to these major findings it emerged that there were inadequate provisions for ethical scrutiny of research at the hospital concerned and that patients were being submitted to several procedures by students and others for which no consent had been given.

Since the report has been published Professors Green and Bonham, who were at the centre of the scandal, have been charged by the Medical Council with disgraceful misconduct and two other consultants who were at the hospital face charges of professional misconduct. The inquiry, however, has had far wider consequences than on the doctors and patients immediately concerned. It raised ethical questions about clinical treatment, teaching, and research and has provoked major changes in New Zealand's teaching hospitals.

\section{Clinical care and teaching}

The doctor-patient relationship has changed: no longer can a doctor expect a patient to comply meekly with decisions without taking the trouble to explain them and obtain consent. Much more patient participation and more open discussion between consultant and patient are now expected. In addition to these informal changes the Department of Health convened a working party to fix national guidelines for informed consent. This committee, however, included no practising clinicians and produced guidelines that were widely regarded as unworkable. They required a quantity and quality of information that far outstripped what most patients would want and made so many aspects of treatment subject to explicit written consent that they threatened to trivialise the whole notion. A second committee is about to review these guidelines in the light of a huge number of dissenting submissions.

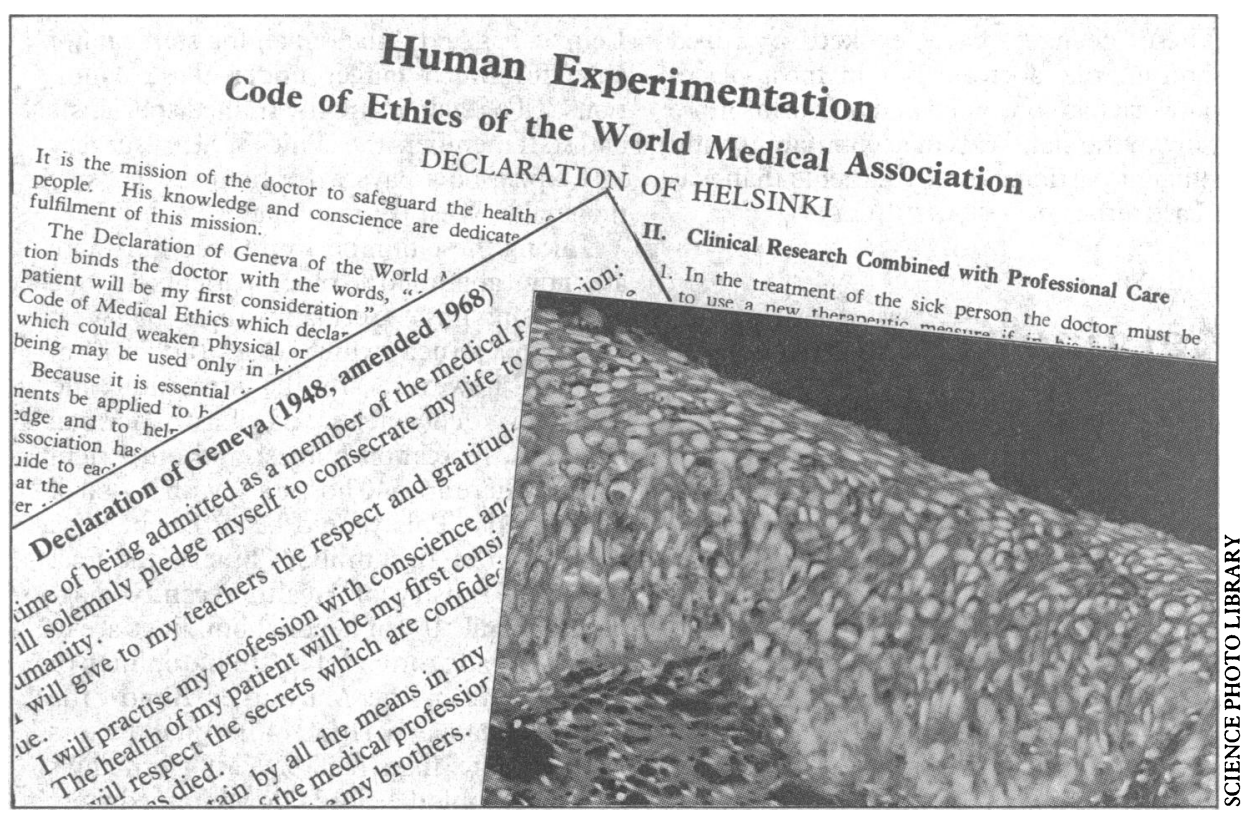

The Cartwright report also suggested that each health board should appoint patient advocates, who would help and represent any patients who felt in need of advice or support in making decisions about treatment. To date one has been appointed-at the National Women's Hospital, where the cervical cancer study was carried out.

Before the Cartwright report most teaching hospitals asked patients whether they were willing to take part in student teaching. The report recommended that all patients should be informed that such participation was entirely voluntary and that their decisions would not influence the clinical care they received. Mostly, patients are now asked to participate and given an opportunity to decline before students are introduced to them, even though no written consent to such participation is sought. This has led to some worries about the availability of suitable patients for training medical students, especially for pelvic examinations in women and other intrusive procedures; many clinical teachers have responded by creative dialogue with patients rather than gloom and despondency. Most centres now seek written permission for such examinations and limit them to a student who is involved in other ways so that there is some semblance of a doctor-patient relationship in place.

The other major effect on teaching has been on the medical curriculum. All medical students now receive 25-30 hours of ethics teaching throughout their course. Topics include the doctor-patient relationship, the relation between ethics and law, informed consent, abortion, embryo experimentation, infertility treatment, genetic manipulation, animal experimentation, irreversible coma, euthanasia, ethical issues in psychiatry, and so on. The teaching is with lectures, small group discussions, and case presentations and seeks to encourage a rigorous and analytical style of thinking, enabling students to evaluate opinions rather than merely form them.

\section{Clinical research}

Clinical research has caused great concern to medical staff. Judge Cartwright recommended that patients entering research trials should give informed consent to their participation and that the research should be approved and monitored by ethics committees with equal lay and medical representation. Both requirements are increasingly being met by all of New Zealand's area health boards.

Patients are now told of the purpose, risks, and potential benefits of any trial in which they are invited to participate and also offered a report on the results at the end of the trial. They are told who the principal investigators are and that they may withdraw at any time without prejudicing their clinical care. Case note reviews are excepted from this because the information gained from these does not relate to individual people and is part of the proper audit function of an academic institution. Many clinicians, however, now tell their patients that notes may be used for these purposes. Reassuringly, in those boards where the research standards have been in place for some time research continues and the attitudes of patients are generally supportive and cooperative.

The new ethics committees look not only at research but also at innovations in clinical treatment that depart from currently accepted practice (this prevents clinical research from masquerading now as one thing and now as another to escape surveillance by a properly constituted ethics committee). What is more, 
the hęalth department has sponsored meetings of the chairpersons of ethics committees from throughout the country to allow pooling of ideas. This has enabled the development of decisions. Where the committees are working smoothly they support and monitor clinical research rather than obstruct academic medicine.

These changes have evoked a mixed response from doctors, but in most places good work has continued and conforms more closely to the standards of accountability and intelligent participation by patients than was the case hitherto.-GRANT GILLETT

\section{Merging German health care systems}

Even before East Germans confirmed their readiness to reunite with West Germany in the elections of 18 March health officials in Bonn and Berlin had begun paper exercises on how to merge two very different health was a stocktaking of health care staffing and supplies in East Germany, because until then its health care statistics were either incomplete or subject to window dressing.

In a recent report the Berliner Zeitung, formerly a mouthpiece of the old regime in East Berlin, publicly admitted for the first time "enormous backlogs" in the medical services of East Germany in comparison with Western countries. In 1989 there was one doctor to about 420 patients-not much worse than in West Germany. From the official estimates of 40840 medical doctors and 12290 dental surgeons, however, several cuts have to be made.

About 5000 doctors in East Germany are pure bureaucrats, exclusively tied to administrative tasks in the health care system. Even if some of them could be reintegrated in hospital and outpatient services they would

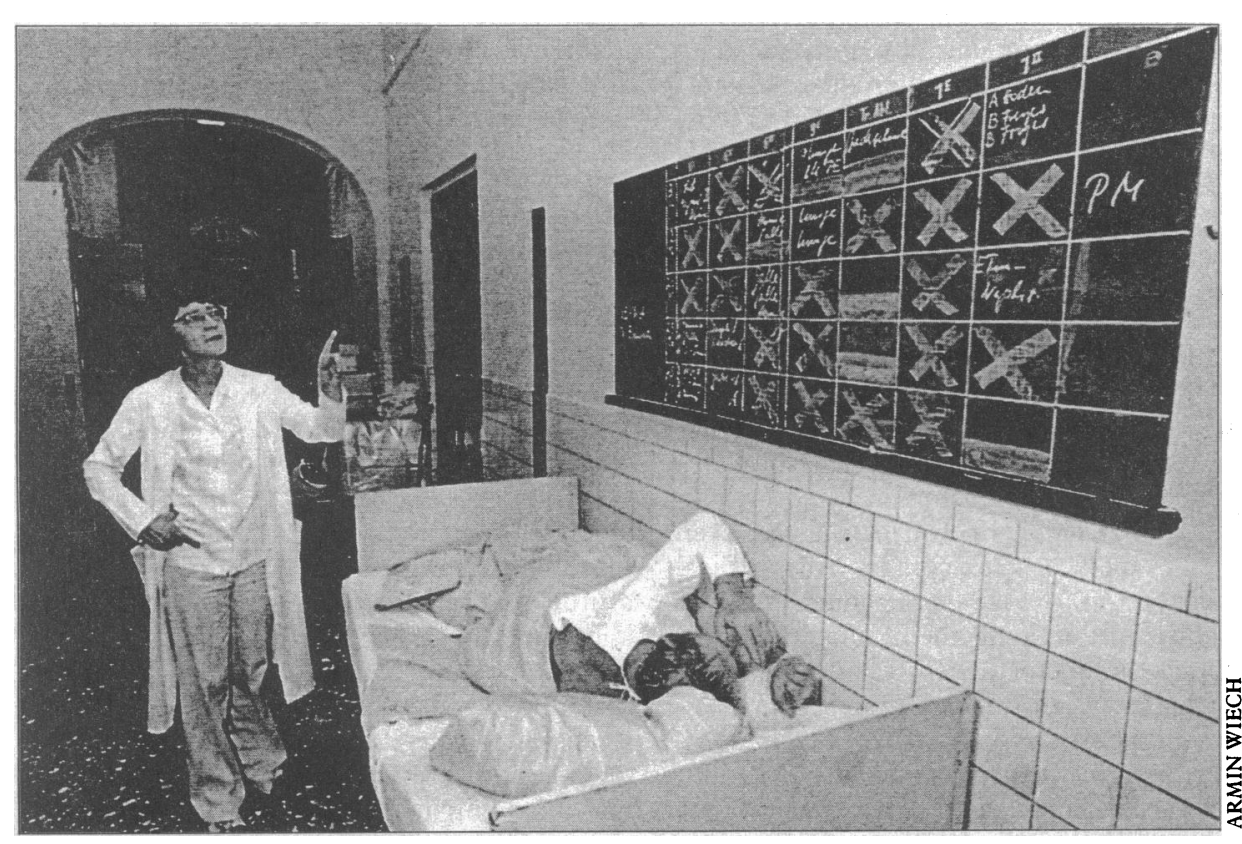

St George's Hospital, Leipzig. Each cross marks a cancelled operation: in recent months Leipzig has lost one sixth of its doctors

be handicapped by a longstanding lack of bedside experience and professional skill. Another 3000 doctors have "gone west" during the past few months, often leaving their remaining colleagues in distress. At hospitals in Leipzig, the second largest city in East Germany, $17 \%$ of the doctors and $21 \%$ of the hospital staff are reported missing. As the vice chancellor of the University of Leipzig has said, "the remaining staff cannot cope for much longer under these conditions." To retain its highly trained specialists and staff members the clinic for heart surgery in Leipzig now pays extra bonuses or "stay money" in West German marks.

Taking these numbers into account, there are now about $30 \%$ more patients to one doctor in East Germany than in West Germany. Much worse than the lack of staffing, however, are the structural and technical deficiencies of East German hospitals, recreation homes, and outpatient wards. There are 540 hospitals, with a total of 70000 beds. This should be sufficient for a population of 16.6 million, but, as the East German Ministry of Health recently diagnosed, about $50 \%$ of hospital buildings are in a "structurally rotten" state. In the opinion of observers from the Marburger Bund-the West German association of hospital doctors - even more than half of East Germany's hospitals would be closed down immediately if Western standards were applied.

Other figures also show the low technical standard of diagnostic medicine in East Germany: automation in hospital laboratories averages $18 \%$, compared with $90 \%$ in Western countries. Waiting lists for computed tomography run to two years.

In a first move East and West German Ministers of Health, Klaus Thielmann and Ursula Lehr, late in February agreed on an aid programme to fill the most urgent needs. One month later West German deliveries to 250 East German hospitals, mostly of drugs, syringes, rubber gloves, and dressings, had reached an equivalent of half a thousand million marks (£190m). The Bonn Ministry some shared skills and orthodoxy in ethical service systems. Firstly, what was needed of Health also encouraged doctors to settle down in East Germany by taking over their social insurance dues, and about 80 West German doctors are now working in East German hospitals.

The big task, however, will remain the merging of two entirely different health service and insurance systems. In East Germany doctors have the status of civil servants and patients are enrolled in a public health insurance scheme. The freedom of setting up wherever they want is as unknown to these doctors as having the choice between private or public insurance is to the patients. "We need big structural reforms ourselves," sighed an official from the Bonn Ministry of Labour and Social Affairs, "How could we now say which elements we should take over and which not?"- HELMUT L KARCHER

\section{Relationship between GP and FPC is a contract}

Three Appeal Court judges have unanimously ruled that the relationship between general practitioners and family practitioner committees is based on a contract between them The judgment reverses a High Court ruling last year that the relationship was not a contractual one. Had that finding stood the result would have been "disastrous in the context of medical services," according to John Davies, head of the BMA's legal department. "It would have meant that if an FPC decided to withhold a payment for whatever capricious reason there would have been no legal redress short of the complicated process of judicial review."

The Appeal Court's verdict means that $\mathrm{Dr}$ Premananda Roy, whose appeal was backed by the BMA, can now bring a simpler action, suing on his contract with Kensington and Chelsea and Westminster Family Practitioner Committee for the reinstatement of his $100 \%$ basic practice allowance. The committee cut his allowance to $80 \%$ from 1 January 1985 , claiming that he was not devoting a substantial amount of time to his practice. The cut was imposed when he was reincluded in the medical list after a 24 hour retirement on his 60th birthday. Dr Roy was away for between one third and one half of each year between 1979 and 1987 . He argues that by employing a locum he satisfied the requirement to devote substantial time to the practice.

Giving judgment, Lord Justic Nourse said that judicial review would be the only remedy if the committee turned down a doctor's application to be included in the list. But the committee's acceptance of the doctor's application created a contract between them. Lord Justice Balcombe said that the fact that neither the FPC nor the doctor had freedom of contract over the terms of service, which were laid down by statute and regulations, was immaterial. If the relationship were not contractual it was difficult to see what else it could be. - CLARE DYER 


\section{Seasickness}

"Man's fingerprint is found everywhere in the oceans" is how the United Nations' report on the marine environment poetically begins. But it turns out that his hands are dirty - "Chemical contamination and litter can be observed from the poles to the tropics and from beaches to abyssal depths." To all the words that poets have used to describe the sea must now be added "dustbin" and "sewer."

Worst off is the coastal strip, where half of the world's population live. Domestic sewage is the main culprit. Earlier views that no demonstrable causal links could be made between human disease and bathing in contaminated water are no longer tenable, according to the report. There is now a good case for establishing microbial standards for bathing areas, it states, based on faecal indicator bacteria (of which Enterococcus species are probably the best). The same urban sewage that leads to bathing problems is also responsible for acute gastrointestinal disorders after the consumption of contaminated shellfish.

Sewage is one of several land based sources of nutrients-others are run off of excess fertiliser, animal wastés from intensive livestock farming, aquaculture, and certain types of industrial effluents - that increase the growth of algae. Oxygen depletion follows, with adverse effects on water quality which is what happened along the Adriatic coast two summers ago.

The sea is not spared the greenhouse effect. Its level is etimated to have risen some $12 \mathrm{~cm}$ this century. A global warming of $1 \cdot 5-$ $4.5^{\circ} \mathrm{C}$ resulting from the doubling of the greenhouse gases predicted for the next decades would raise sea level by $20-140 \mathrm{~cm}$, mainly by thermal expansion of ocean water.

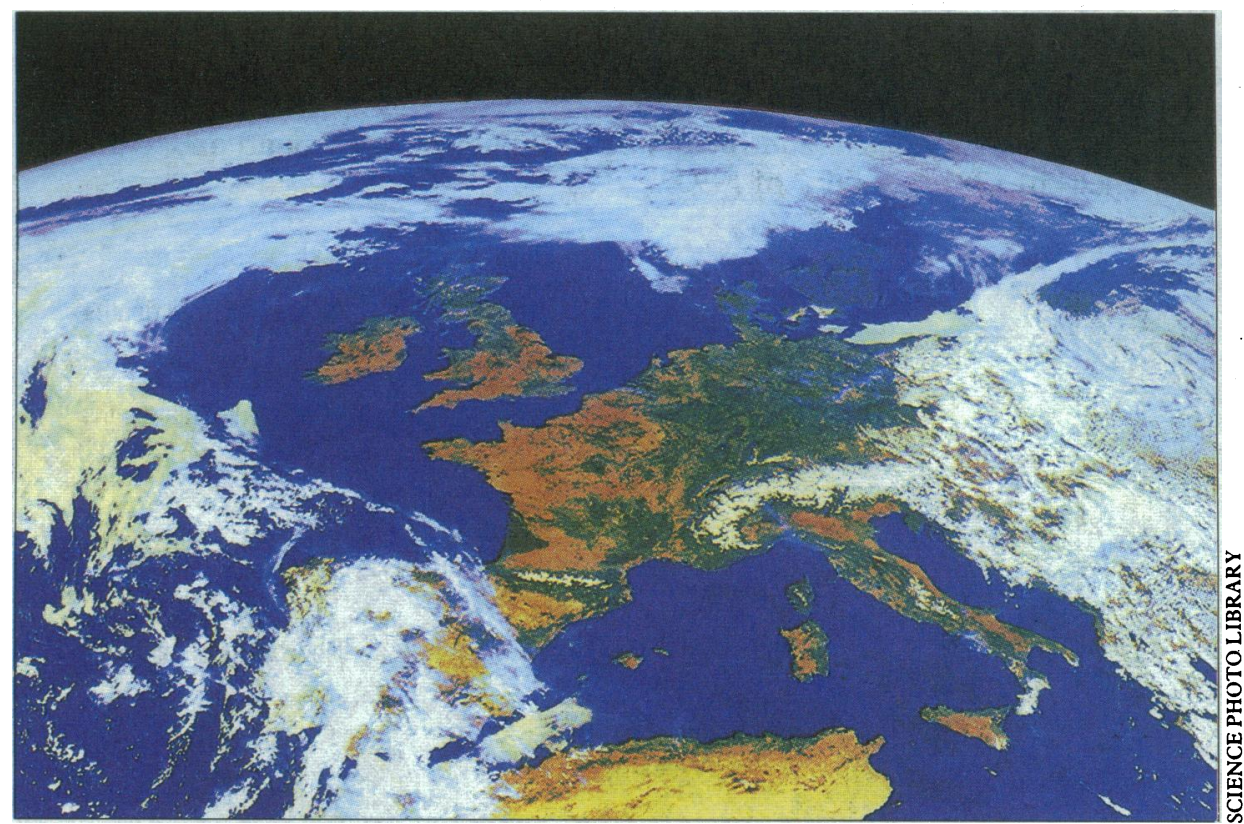

From shore to stinking shore

Such a rise would have its greatest impact in coastal regions-several islands in the Pacific and Indian oceans might become uninhabitable as a result.

What can be done? A better legal framework, both national and international, is needed to protect the marine environment. Legislation was enacted early on to control oil pollution-what the report describes as the most visible and objectionable form of pollution. More recently, dumping at sea and pollution by chemicals and litter and, increasingly, by nutrients have become the subject of regulation. Hard choices need to be made because effective control may be costly-sewage treatment and disposal facilities for the 132 million inhabitants of the Mediterranean coastal settlements lacking these would cost about $\$ 18$ billion, or $\$ 150$ per head.

The report points out that pollution per se is not the only threat to the oceans: runaway coastal development is just as damaging to habitats and marine resources. "No international agreements or guidelines on coastal development are available, and this gap should be remedied well before most areas are built up, mangroves cut down, swamps and lagoons reclaimed and coral reefs destroyed," the report concludes.-TONY DELAMOTHE

The State of the Marine Environment (report No 39) was UN/UNEP joint group of experts on the scientific aspects of marine pollution (GESAMP) and is available from any of the sponsoring agencies. prepared by the IMO/FAO/Unesco/WMO/IAEA

\section{For anthrax isle the chemical war is finally over}

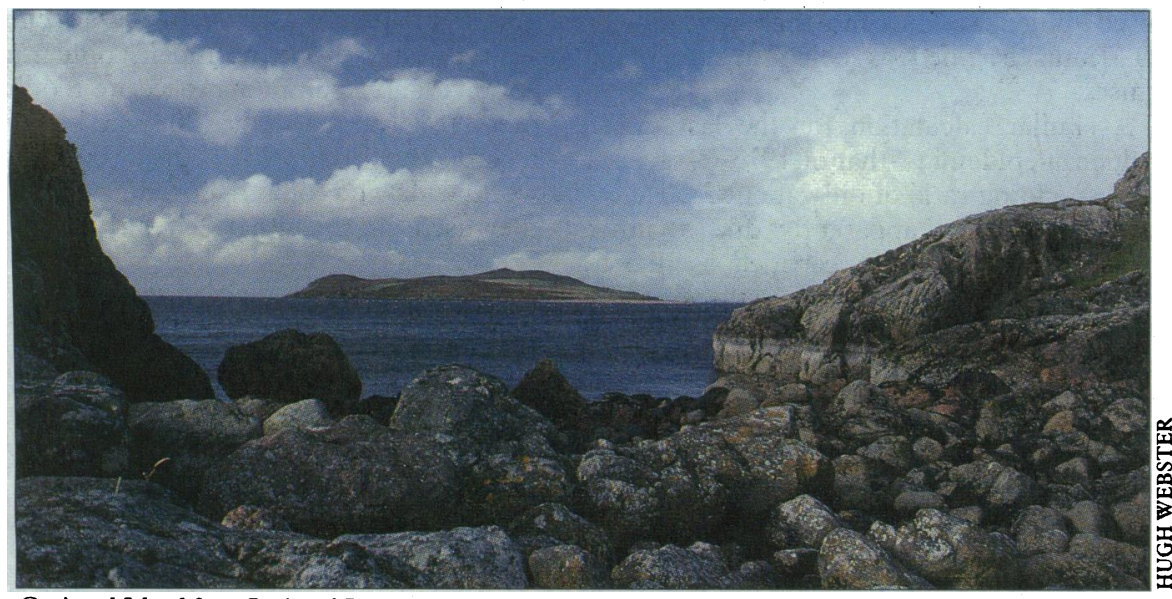

Gruinard Island from Gruinard Bay

Sheep may now safely graze on Gruinard, a small Scottish island deliberately contaminated with Bacillus anthrax in the second world war.

Gruinard was chosen for the trials of Britain's first biological weapons; it was remote and uninhabited. In 1942 and 1943 some $4 \times 10^{14}$ anthrax spores were released on the island by electrical detonation of small bombs. Sheep downwind from the detonation point inhaled lethal quantities of the spores and quickly died, confirming the effectiveness of the weapons. The billions of spores scattered over the island settled into the soil, and after the war sampling of the soil suggested that the island would remain dangerously contaminated until around 2050

The heavy contamination was, however, concentrated into one small area of about 3 ha $(7 \cdot 4$ acres $)$. The Chemical Defence Establishment concluded that decontamination was feasible. An independent advisory group recommended increasing the area to be treated to $4 \cdot 1$ ha $(10 \cdot 1$ acres $)$. The vegetation was sprayed with a brushwood killer and then burnt. Next, $50 \mathrm{~km}$ of irrigation tubing was pegged down over the site and 280 tonnes of formalin diluted in 2000 tonnes of seawater was sprayed over the site. Two months later the soil was resampled and some sites were found to need further applications of formalin. One year later the treated area was seeded with a grass mixture. Sheep were allowed to graze freely over the island and all remained healthy. The island is now deemed "safe to return to civil use."TONY SMITH

Proceedings of the International Workshop on Anthrax 11-13 April 1989 (Salisbury Medical Bulletin January 1990, No 68 (special supplement)) is available from Dr P C B Turnbull, PHLS-CAMR Porton Down, Salisbury, Wiltshire; price £18 (including postage) 
Hidden influenza deaths

\section{No of deaths by cause and incidence of influenza in England and Wales, week 44 of 1989 to week 7 of 1990}

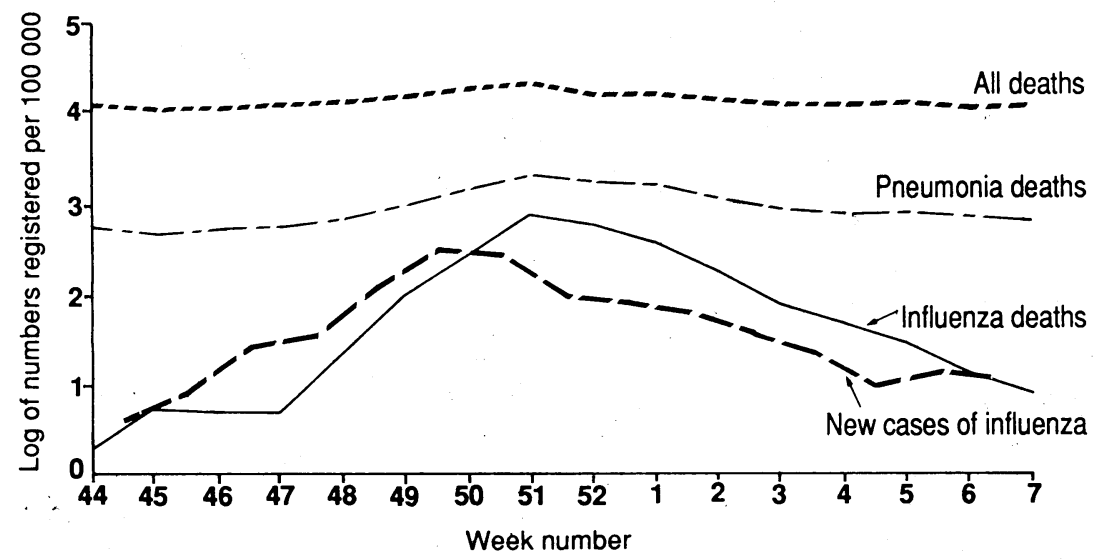

The recent influenza epidemic was the worst to have hit England and Wales since 1976. It may have been responsible, directly or indirectly, for about 26000 deaths, although only about one tenth of these were attributed to influenza by the doctors who certified them.

The course of the epidemic may be charted by means of four series of weekly statistics published by the Office of Population Censuses and Surveys (figure):

(1) The number of deaths registered and provisionally ascribed to influenza

(2) The number of deaths registered other than those in (1) and provisionally ascribed to pneumonia

(3) The total number of deaths registered

(4) The estimated incidence of new cases of influenza reported by general practitioners.

The first sign of an influenza epidemic was an increase during the week ending 21 November in the incidence of the infection -there were 24.6 cases per 100000 population compared with 3.4 and 7.6 cases per 100000 in the previous two weeks. During the week ending 1 December (the week for death registrations is taken as ending on Friday, but for general practitioner data as ending on Tuesday) the total number of deaths increased from 11244 to 12289 , those due to pneumonia going up from 632 to 969 . A week later the number of deaths due to influenza increased from 16 to 102 . By the week ending 22 December the total number of deaths registered had reached 19180 - the highest number recorded since during the peak of an influenza epidemic in December 1969. Of this total, 786 were ascribed to influenza and 2064 to pneumonia. By this time the peak of new cases reported by general practitioners had passed, and by the middle of February all of the series were back to a more or less normal level.

Isolations of influenza virus were first reported by the Public Health Laboratory Service Communicable Disease Centre in the week ending 24 November. The number continued to increase for about four weeks. Virtually all of those typed were influenza A. In view of the close correspondence be- tween the patterns of total mortality and the indices of influenza it is difficult to escape the conclusion that most of the "excess" deaths were caused by a common agent. The total number of excess deaths that occurred during the epidemic can be roughly estimated by comparing the numbers of deaths in the 12 weeks from 19 November to 9 February with the average numbers in the corresponding weeks of the three previous years, during which there was a very low incidence of influenza (although average winter temperatures were lower than in 1989-90). On the basis of this comparison the number of excess deaths was 26080 , of which only 2440 were certified as being due to influenza and a further 5260 to pneumonia. As low temperatures tend to increase the numbers of excess deaths during winter this is probably an underestimate of the excess mortality associated with the 1989-90 epidemic. It seems, therefore, that for every death for which the certifying doctor recognised influenza as the cause there were at least 10 deaths certified as being due to other causes.

A similar calculation for the last major influenza epidemic - that of 1975-6-gives a corresponding ratio of only about $2 \cdot 5$ excess deaths that were apparently due to other causes for every death certified as due to influenza. This change in the ratio generally applied to all of the years after 1976 during which the incidence of influenza was low as well as to the recent epidemic. If it persists the true impact of future epidemics will have to take account of these findings. - MICHAEL CURWEN, KAREN DUNNELL, JOHN ASHLEY

\section{Clarke says contract review is possible}

The Secretary of State for Health has decided not to amend the general practitioners' contract to exclude certain patients from the cervical cytology target groups. He argues that current targets already allow for one in two or one in five women in the eligible groups refusing. To extend the exemptions would undermine the objective of reducing the 2000 avoidable deaths annually from cancer of the cervix.

The Department of Health has been under pressure to allow women to exclude themselves from practice target groups by signing a form declining the offer of a smear test $(24$ March, p 769). Mr Clarke, however, has decided that the health aims must have priority over further target concessions. He believes that the problem could be eased by having more women GPs, especially in practices serving ethnic minorities.

$\mathrm{Mr}$ Clarke told journalists that family doctors' biggest worry was the extra workload of health checks for all new patients and every three years for adults on their lists. He said that doctors are reassured when they are told that the checks can be done by practice nurses. He says that his mind is open to a review of the contract at the end of its first year. A few days before the start of the new contract on 1 April Mr Clarke said: "I would like to get into a sensible relationship with the doctors. We can review the target from time to time to see if it is working. If it is not having its effect let us review it."-JOHN WARDEN

\section{Dalkon claims}

As the end of the 15 year compensation battle over the Dalkon Shield intrauterine contraceptive device looms, settlement offers for women without full medical records to document their injuries were described last week by the Dalkon Shield Association, the British victims' group, as "derisory and hurtful."

Some 3000 British women are among 100000 world wide who have received packets from the United States based Dalkon Shield Claimants' Trust detailing the two main options for compensation. The association says that victims will be forced to choose between inadequate compensation under option 2 and a complex procedure requiring them to produce up to 20 years' medical records under option 3 . Some 85000 women world wide who could not produce proof that they used the shield have already accepted a

\section{This week's contributors}

Michael Curwen is a statistician, Karen Dunnell is assistant chief medical statistician, and John Ashley is deputy chief medical statistician at the Office of Population Censuses and Surveys

Tony Delamothe is an assistant editor of the $B M \mathcal{F}$

Clare Dyer is the BMF's legal correspondent Grant Gillett is consultant neurosurgeon at Dunedin Public Hospital and senior lecturer in medical ethics at Otago University Medical School

Helmet L Karcher is a science writer in Munich

Tony Smith is deputy editor of the $B M \mathcal{F}$

John Warden is the BMY's parliamentary correspondent 
flat $\$ 750$ under option 1 . The trust is also offering up to $\$ 15000$, deductible from final compensation, for in vitro fertilisation or tubal surgery for women under 45 who have been left infertile by the shield.

The device, widely used in family planning clinics, was withdrawn from the market in 1974 (1975 in Britain) after reports of pelvic inflammatory disease, septic abortions, and death. The $£ 1.5$ billion trust fund was set up as part of a takeover of its manufacturers, A $\mathrm{H}$ Robins, by American Home Products after Robins filed for financial reorganisation in the face of an avalanche of lawsuits.
Offers under option 2, which requires women to prove only that they used the shield and suffered one of several specified injuries, range from $\$ 850$ for shield users who conceived and had to have an abortion to $\$ 5500$ for those who underwent a hysterectomy. Marlene Winfield, organiser of the Dalkon Shield Association, last week asked the trust to double the offers under option 2 and revise the requirements for option 3.

Compensation under option 3 is unspecified, but lawyers representing victims believe that it will match previous court awards and settlements agreed by Robins and could top
$£ 150000$ for the most serious injuries. But around $20 \%$ of the women represented by lawyers have been unable to get complete records. Hospitals, family planning clinics, and, in fewer cases, general practitioners have destroyed old records. In many cases doctors recorded that they inserted an intrauterine device but did not name the device.

Ms Winfield said: "A cooperative GP can make all the difference to a woman's case. Some have been extremely helpful while, sadly, others have given wrong information or refused to hand over records."-CLARE DYER

\section{Letter from Westminster}

\section{Shaping tomorrow's world}

Those at the back cry "Forward!" Those at the front cry "Back!" While Kenneth Clarke presses ahead with the NHS reforms the medical royal colleges are leading a campaign to slow him down. The Secretary of State for Health shows not the slightest intention of doing so and will send the troops over the top at dawn on 1 April 1991 precisely as planned.

"I am far more confident than I ever was that the 1991 date is sensible and the progress we are making on the ground makes it beyond doubt that it is practical," Mr Clarke said in response, much in the manner of a commander in chief directing operations from his rear headquarters in Richmond House.

Mr Clarke plainly has an advantage over his critics. He has the overall battle plan laid out before him and the power to deploy the resources necessary to push it through. $\mathrm{He}$ also has possibly the best staff officers of their kind ever assembled in Whitehall and I suspect it is from them that he derives his confidence.

At any rate I made it my business last week to identify Clarke's aides de camp and how they are going about their task. There is no great secret about who's who. The early reforms created a policy board under Clarke and a management board under Duncan Nichol, the newly arrived NHS chief executive. This combination of thinkers and doers, which failed when it was tried five years earlier, works with Clarke and Nichol so that policy and operations are closely entwined.

In the past year Nichol has hand picked his executive team, which is now complete with the appointment of Peter Griffiths as his deputy and Eric Caines as personnel director. The striking thing is that the top half of the 10 strong management board comprises experienced health service managers, like Nichol and Griffiths, and outside specialists, such as Sheila Masters, the finance director from Peat, Marwick, McLintock. As a result, the show is being run less by career civil servants than by streetwise NHS managers.

That is an important distinction. It means that the stamp of Nichol's executive is rather more than that of a head office concerned only with management systems, as was the old management board. The new executive is uninhibited about its right to influence policies. Where there are policies on how to develop management capacity, extend pay flexibility, or, above all, on the delivery of patient care, Nichol and his executive expect to be in the driving seat.

They would not dispute their remit to reform the NHS being likened to making the Co-op as efficient as Marks and Spencer. The starting point, of course, was the white paper Working for Patients. Out of that 34 separate projects were evaluated in order to test the application of the white paper's principles in practice. Along the way regional managers were drafted in directly from the health service to work on project briefs, some of which took shape as clauses in the NHS bill. The process was refined so that now the implementation of the white paper revolves around eight key projects-namely, NHS trusts, general practice fund holders, human resources, health authorities, funding, information technology, contracts, and communications (loosely defined as the winning of hearts and minds).

Managers for these projects report to Peter Griffiths, who is in charge of implementing the white paper. Working with him, Dr Diana Walford, deputy chief medical officer, is the executive's medical director, in control of medical manpower and the development of clinical audit. Catherine McLoughlin, a former district general manager, is the executive director of nursing, with Bryan Rayner, a career civil servant, the director for family practitioner services.

\section{Shift to application}

Working thus, the executive team has so far succeeded in hitting all the target dates in the timetable for shaping the original policy into a working model. A landmark has been reached where from now on the flow of paper guidance will diminish and the emphasis will shift to application and making the reforms happen. There will be a hands on drive reaching down to unit managers.

Once the NHS bill receives royal assent in June the pace will noticeably quicken. The new, smaller health authorities will be appointed. Self governing hospital trusts will be set up in shadow form (after a process

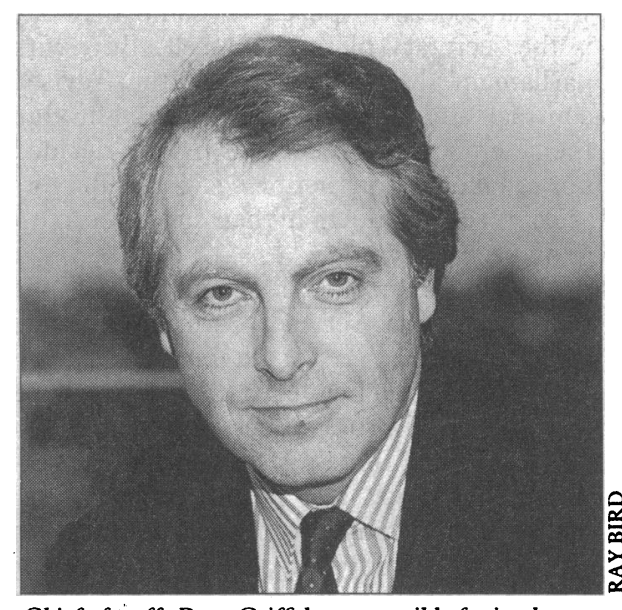

Chief of staff, Peter Griffiths, responsible for implementing the white paper

of public consultation which should prove interesting), general practitioner fund holding practices will be selected, and health districts will begin to translate their existing activities into contract terms. This process will also necessitate close contact with general practitioners to decide future referral patterns. Taken together, these are seen as the key tasks to be accomplished between now and the end of September.

It all amounts to an innovative agenda being superimposed on a working health service that has to remain stable in terms of finance, organisation, and patient activity. Nor do the central planners envisage any great upheaval in the first year after April 1991. They will expect the contract system to exert pressure for a higher quality of treatment and to make hospital administration more user friendly. But the watchword seems to be stability rather than any dramatic change in the levels of patient treatment. For Nichol and his team it means creating tomorrow's world while keeping today's one quiet.

The likelihood, however, is that their political masters are going to demand the best of both worlds. When that happens the ordered calm of staff headquarters in Richmond House will give way to the battlefield chaos of a general election and the ultimate test of Mr Clarke's strategic plan.-JOHN WARDEN 


\section{GPs' chairman promises doctors will do their best for patients}

Weekend rioting in London's streets over the poll tax and among prisoners in Strangeways Prison, Manchester, over the appalling overcrowding are chilling evidence of how violence lurks close to the surface of even a seemingly stable and civilised society. Nevertheless, angry though people may be over the changes in the NHS, I cannot imagine them being stirred to such violence. The first of these changes happened to coincide with the weekend's unhappy events - namely, the introduction on 1 April of Kenneth Clarke's imposed contract for general practitioners.

Certainly, the only April fool that doctors will have been disposed to name that day is the secretary of state himself. But, with parliament having endorsed the revised contract and general practitioners through their democratic procedures having decided not to take militant action against it, doctors are now settling down in their surgeries to try to make it work.

Dr Michael Wilson, chairman of the General Medical Services Committee, while criticising some parts of the contract as being "misguided and ill conceived," has promised that doctors will do their best for the patients. "But," he continues in his 1 April press statement, "they will monitor the defects of the new arrangements and continue to press the government to change the contract. General practitioners are determined to do all they can to protect patients from the deficiencies.... Secretaries of state come and go, but general practitioners will continue to care for their patients." That is true, but this particular secretary of state looks set to leave some unhappy memorials behind.

\section{Labour party's plans for contract}

Meanwhile, as I write this page, the Labour party has declared its future intentions for the contract. Given its big lead in the opinion polls, we must take these seriously. Briefly, the opposition is on common ground with the government on minor surgery, night visits, public information, and retirement age. It wants to keep a watching brief on health checks, examinations of older patients, and the increased administrative burden. But three elements the Labour party would change urgently in consulttion with the profession:

- A reduction in the capitation element to below a half of income and a cut in maximum list sizes

- Restore a full incentive for cervical cancer screening to those doctors whose practices face difficulty in reaching the upper target

- Negotiate a more flexible assessment for the new deprivation allowance.

One essential element in trying to make the new contract work will be accurate up to date information. Indeed, such information in general practice will be crucial to the effec-

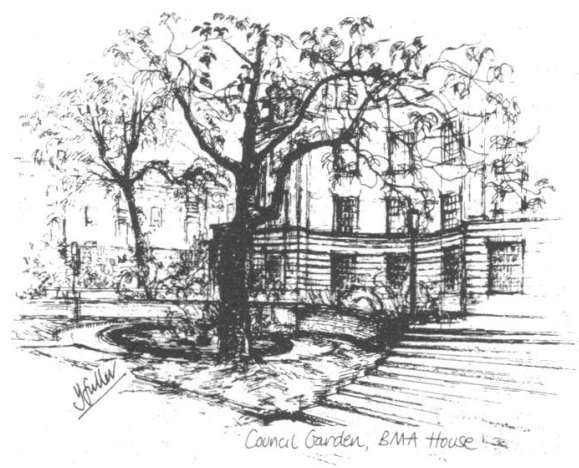

customary combative defence of the government's annually rising allocation of money to the NHS. This year his coda has been to lav the blame for overrun budgets on sloppy management, a state of affairs that he argues will be cured by his forthcoming reforms. You may hark to Mr Clarke's aria as you please; I am more inclined to listen carefully to the fortissimo chorus of clinicians declaiming on what is happening down on the wards. Take the contribution from Dr A Jaleel, who works in Darlington District Health Authority and who chairs his regional consultants committee.

If Darlington Health Authority approved

tiveness of the government's NHS reforms as a whole, which the secretary of state hopes to launch on April fool's day 1991. For several years now Dr James Read, a general practitioner in Loughborough, has been developing a clinical classification code for general practice data. In 1988 the joint computer group of the Royal College of General Practitioners and the GMSC reported on classification of data, recommending that the Read clinical classification be adopted as a common code for general practice. The Department of Health has accepted this and reached agreement with $\mathrm{Dr}$ Read about the use of his code.

In a letter to the BMA the department says that the classification will need modifying and regularly updating. The department proposes to set up a government funded NHS Centre for Coding and Classification to do this work. This centre will be responsible to a supervisory board of 10 , containing at least five doctors - two general practitioners, two hospital clinicians, and one public health physician. Dr Read is to be a director of the centre. The department foresees that the versatility of the Read code means that it will play "a significant part in health information systems."

Information, as we all know, is power, and with the reformed NHS dependent on accurate up to date information effective professional participation in this new structure will be essential. I understand that the executive committee of the BMA council was due to discuss the government's plan on 4 April, when I'm sure that it will have taken up the department's invitation to nominate a doctor to the supervisory board - the GMSC and the Royal College of General Practitioners have also been asked to nominate someone. This may be the first time that some doctors will have heard of the Read classification code. Clearly, however, it is a code with which they will need to become familiar.

\section{Sharp end views on underfunding}

Doctors have once again been giving their sharp end views on what they believe to be the consequences of inadequate funding, while Kenneth Clarke has been making his its new district plan one surgical ward in four would close and surgical lists would have to be rearranged. In addition, waiting lists for hip replacements and treatment for other painful conditions were likely to lengthen because there was not enough money to appoint another consultant rheumatologist.

This experience is not unique, as is shown by a survey that the CCSC has conducted on the financial position of short stay hospitals.

- The Royal Hampshire County Hospital, Winchester, was running into deficit by September 1989, and over 40 beds have been closed to keep overspending below $£ 500000$ staff are under "horrendous pressure," and cuts have reduced the amount of work they can do, with the orthopaedic department particularly badly hit

- In the Royal Hallamshire Hospital, Sheffield, 28 surgical beds have been closed, and these are unlikely to be reopened in the new financial year

- There should be 17 intensive care beds at the Queen's Medical Centre, Nottingham, but "it is a long time since . . . more than eight or nine beds [have been] open," with the result that theatre time is often lost

- The Nuffield Orthopaedic Centre, Oxford, had money from the government's waiting list initiative, but with the health authority unable to fulfil a promise to match these funds 100 fewer hip replacement operations have been done; discovering this, medical equipment firms, which take clients to the centre to see show case operations, decided to pay for some implants.

These are just a few examples and I'm sure that clinicians elsewhere could produce many similar experiences. But this anecdotal evidence - reinforced by a BBC Radio 4 survey and an excellent This Week programme on ITV ( 29 March) - convinces me that money is still damagingly short. And, pace $\mathrm{Mr}$ Clarke, whose comfortably furnished Richmond House office contrasted with the tatty wards on the programme, I doubt that his structural and management changes will bring adequate respite to patients and clinicians.

SCRUTATOR 